\title{
Evaluation of the Relationship between Personality and Conservatism of Investors in the Stock Exchange (Case Study: Insurance Companies)
}

\section{Evaluación de la relación entre personalidad y conservadurismo de Inversores en Bolsa (Estudio de caso: Compañías de seguros}

\author{
Mahsa Mohseni \\ Islamic Azad University, firozkoh branch, Tehran, Iran \\ ORCID ID: https://orcid.org/0000-0001-5180-9078
}




\section{Summary}

The purpose of this research to "investigate the relationship between personality and conservatism of investors of insurance companies listed on the Tehran Stock Exchange." The present study was applied research in terms of purpose, which has employed a descriptive and correlational method. The statistical population of this research included all people who buy and sell shares of insurance companies listed on the Tehran Stock Exchange. According to Cochran's formula, the sample size was determined as much as 384 people collected by a simple random sampling method. The research instruments were the Conservative Questionnaire based on the Gribel and Leighton (1999) and McCrae and Costa (1985) five-factor personality questionnaire. The questionnaire's validity was confirmed by 20 experts, and the reliability of all three questionnaires was acceptable for all three questionnaires due to Cronbach's alpha above 0.79 . The data analysis was conducted using the Pearson correlation test and regression analysis. The results indicated a significant relationship between the investors' personality and their conservatism in the Tehran Stock Exchange. There was also a significant relationship between all personality components except for extraversion with the investor's conservatism in the Tehran Stock Exchange.

Keywords: the five-factor model of personality, conservatism, investors, insurance companies.

\section{Resumen}

El propósito de esta investigación es "investigar la relación entre la personalidad y el conservadurismo de los inversores de las compañías de seguros que cotizan en la Bolsa de Valores de Teherán". El presente estudio fue una investigación aplicada en términos de propósito, que ha empleado un método descriptivo y correlacional. La población estadística de esta investigación incluyó a todas las personas que compran y venden acciones de compañías de seguros que cotizan en la Bolsa de Valores de Teherán. Según la fórmula de Cochran, el tamaño de la muestra se determinó hasta 384 personas recolectadas mediante un método de muestreo aleatorio simple. Los instrumentos de investigación fueron el Cuestionario Conservador basado en el cuestionario de personalidad de cinco factores de Gribel y Leighton (1999) y McCrae y Costa (1985). La validez del cuestionario fue confirmada por 20 expertos, y la confiabilidad de los tres cuestionarios fue aceptable para los tres cuestionarios debido al alfa de Cronbach por encima de 0,79. El análisis de los datos se realizó mediante la prueba de correlación de Pearson y el análisis de regresión. Los resultados indicaron una relación significativa entre la personalidad de los inversores y su conservadurismo en la Bolsa de Valores de Teherán. También existía una relación significativa entre todos los componentes de la personalidad, excepto la extraversión, con el conservadurismo del inversor en la Bolsa de Valores de Teherán.

Palabras clave: el modelo de cinco factores de personalidad, conservadurismo, inversores, compañías de seguros.

\section{Introduction}

The stock exchange is an economic market in which market participants buy and sell securities under specific rules and regulations. This market is risky and professional, and in most cases, investors are dissatisfied because mistakes often undermine their financial goals. Investors can perform better and adhere to a well-codified plan if they know themselves better and try to correct these mistakes (Pompein, 2009). With the comprehensive development of psychology, especially behavioral sciences, and the natural influence of this science in other humanities gradually affected the theoretical framework of sciences, such as sociology, economics, management, and accounting and financial management in the comparative process and practically made a theoretical inflection point in humanities research (Rai and Fallahpour, 2004). Financial behavior is a type of theory, which describes financial issues using the theories of cognitive psychology. This theory hesitates the predictions of modern financial theories such as 
efficient markets and is skeptical of theories such as expected maximization and rational expectations at the micro-level. One of the essential research programs of financial knowledge that is at the forefront of rejecting the theory of efficient markets is the theory of financial behavior, which is the result of joint efforts between financial sciences and social sciences and has deepened our knowledge of financial markets. In Western economic literature, the human beings' existential nature is defined as a rational being that makes decisions under precise conditions. After decades of research, personality psychologists are approaching a general consensus on human personality traits, including a five-factor model or the five main personality factors (Shaker and Bigdeli , 2018). According to this model, personality is composed of five main dimensions, which are neuroticism (or in other words, emotional stability), extraversion (or activity), openness to experience (or culture or intellectualism), compatibility, and conscientiousness. The two factors of extraversion and consensus are related to personality traits of an interpersonal nature. The studies in the field of investment showed that the irrational behavior of some male and female investors is contrary to the two main financial-standard bases. Keynes (1936) introduced the popular term "animal spirits" in the stock market. The emergence of multiple contradictions in the investors' behavior, whether male or female, with financialstandard assumptions is coincided with the emergence of a paradigm that is capable of answering unresolved financial-standard problems. Thus, a scientific revolution occurs as a political revolution in which a paradigm is introduced that not only eliminates the shortcomings of the previous paradigm, but also provides a better analysis of investor behavior. This new paradigm, called "financial-behavioral," speaks to the limitations of "arbitrage" and the effects of psychological and gender factors on investor behavior. According to studies, both male and female investors have entered the investment arena because of a sense of need for business and personal independence. Female investors have different motivations for varying skill levels, more reasonable risks, and less diversified investment than their male counterparts. The initiating factors of female investors are also at odds with what drives male to do so, especially in terms of support systems, financial resources, and problems. The initiating investment is another area in which male and female investors are differentiated. Males benefit from bank loans or personal loans as a source of funding in addition to private capital. In most cases, women rely solely on their personal assets or savings. Evaluating the third factor of success of capital market analysts or analysts' personality traits and their effect on their performance is also one of the critical issues that have been examined. The results showed investors have two specialties of fundamental analysis and technical analysis (the first two dimensions of success), and the effect of their personality traits (third dimension) on their performance has been evaluated (Jafari kang et al., 2017). Accordingly, a research was conducted to identify the factors affecting the real investors' decision-making behavior in the Tehran Stock Exchange to provide their behavioral decisionmaking model and determine the validity of that model. The results indicated that culture affects not only the individuals' cognitive process but also the judgment, personal self-confidence, and processing of information or knowledge of a person (Abdul Rahimian et al., 2018).

\section{The importance and necessity of the research}

According to various types of research, most investors, even the most skilled and educated, often rely on emotion in their decisions. It can be concluded that awareness of the importance of psychological factors in investment decisions, which is the purpose of studying behavioral finance, plays an essential role in improving these decisions and ultimately the investors' financial performance. If investors know themselves better and try to correct these mistakes, they can have better functional performance and stick to a well-codified plan (Pompein, 2009). Decision theorists have always tried to prevent the intervention of the decision-makers' personality and specific values in their decisions. However, efforts to rationalize the decision as a critical factor play a key role in their decisions. People's views on the degree of risk-taking and their experience are involved in their decision-making. In many cases, informing real investors about such personality and behavioral traits helps them mainly overcome these traits. Considering that there are not many types of research regarding the Iranian stock market to measure the severity of these biases and behavioral characteristics, it seems that it is very necessary to pay attention to this type of research. Understanding the decisions of successful investors can reveal how they deal with 
mental traps. Financial behavior is a type of theory, which describes financial issues using theories of cognitive psychology. This theory hesitates the predictions of modern financial theories such as efficient markets and is skeptical of theories such as expected maximization and rational expectations at the micro-level. This approach addresses the fact that behavioral and cognitive tendencies can influence the financial assets' prices, contrary to standard financial discussions and theories. Contrary to the theories and approaches of Sharp and Marquette, the issues of financial behavior and investment are the issues of individuals and ways that collect and use information. This aspect of financial and investment decisions seeks to understand and predict the involvement and effect of psychological decisions in the regular financial market (Naseri et al, 2018).

\section{Methodology}

The present research is applied in terms of purpose, descriptive and correlational-survey in terms of data collection and causal in terms of the relationship between variables. In this study, the statistical population includes all people who buy and sell in the shares of insurance companies listed on the Tehran Stock Exchange.

The main hypothesis in this research is to investigate the relationship between investors' personality traits and their conservatism in Tehran Stock Exchange insurance companies. Thus, convenience random sampling method was selected based on the characteristics of the statistical population. Cochran's sample volume estimation formula was used to determine the required sample size (Khalatbari, page 129). In the present study, this variable is taken from the model of Gribel and Leighton (1999) and includes 13 components. In this standard questionnaire, the level of conservatism is measured such that first each of the selected options in each item is separately given a score between 1 and 4 . Then, based on the scores earned, the level of risk is as follows:

1) Score 18 and lower: Low risk tolerance (low risk-taking). This is called a conservative investor.

2) Score 19 - 22: Risk tolerance below average (below average risk-taking)

3) Score 23 - 28: Medium risk tolerance (moderate risk-taking)

4) Score 29 - 32: Risk tolerance above average (above average risk-taking)

5) Score above 33: High risk tolerance (high risk-taking).This is called an aggressive investor.

Table 1. Coding the scores of all items except item 1

\begin{tabular}{|c|c|c|c|}
\hline $\mathbf{a}$ & $\mathbf{b}$ & $\mathbf{c}$ & $\mathbf{d}$ \\
\hline $\mathbf{1}$ & $\mathbf{2}$ & $\mathbf{3}$ & $\mathbf{4}$ \\
\hline
\end{tabular}

Table 2. Scoring the Scores of Question 1

\begin{tabular}{|c|c|c|c|}
\hline $\mathrm{a}$ & $\mathrm{b}$ & $\mathrm{c}$ & $\mathrm{d}$ \\
\hline 4 & 3 & 2 & 4 \\
\hline
\end{tabular}

Explanation: Item 1 is reversed.

\section{Five-factor personality model questionnaire}

The standard questionnaire of the five-factor personality model is taken from McCrae and Costa research in 1985 and includes 60 items based on the five-point Likert scale.

Table 3. Title of items related to the five-factor personality model

\begin{tabular}{|l|l|l|}
\hline No. & Dimensions & Components (questionnaire items) \\
\hline 1 & Extraversion & $2-7-12-27-32-37-42-47-52-57$ \\
\hline 2 & Compatibility & $4-9-14-19-24-29-34-39-44-49-54-59$ \\
\hline 3 & Conscientiousness & $5-10-15-20-25-30-35-40-45-50-55-60$ \\
\hline 4 & Neuroticism & $1-6-11-16-21-26-31-36-41-46-51-56$ \\
\hline 5 & & \\
\hline
\end{tabular}


Various methods are used to calculate the reliability coefficient of the questionnaire as a tool for measuring information and the present research used Cronbach's alpha method. The reliability of the questionnaire used in this research is evaluated by Cronbach's alpha value after duplicating the questionnaire and analyzing the preliminary results by SPSS software.

Table 4: Questionnaire Analysis

\begin{tabular}{|c|c|c|}
\hline Questionnaire & Total Cronbach's alpha & Reliability level \\
\hline Conservatism & 0.851 & High and acceptable \\
\hline $\begin{array}{c}\text { Five-factor personality } \\
\text { model }\end{array}$ & 0.793 & High and acceptable \\
\hline
\end{tabular}

As seen in Table 4, Cronbach's alpha of both questionnaires is in a good code between 0.79 and 0.85 . Therefore, the questionnaires have a good level of reliability.

\section{Results}

At the beginning of this section, the collected data were analyzed and the statistical conclusions were drawn about the questions raised. The data obtained from this study were analyzed using SPSS software. In this section, first, the demographic data obtained from the research questionnaires were statistically described, and then the assumptions and questions raised were examined, and the data were analyzed at both descriptive and inferential levels.

\section{Descriptive statistics results}

Summary of information about descriptive statistics was given in Figures 1 and 2, indicating that in terms of participants' gender, the majority of the information collected belongs to men. In terms of marital status, most of the information collected belongs to married people.

Chart 1. Descriptive information about gender and marital status variables
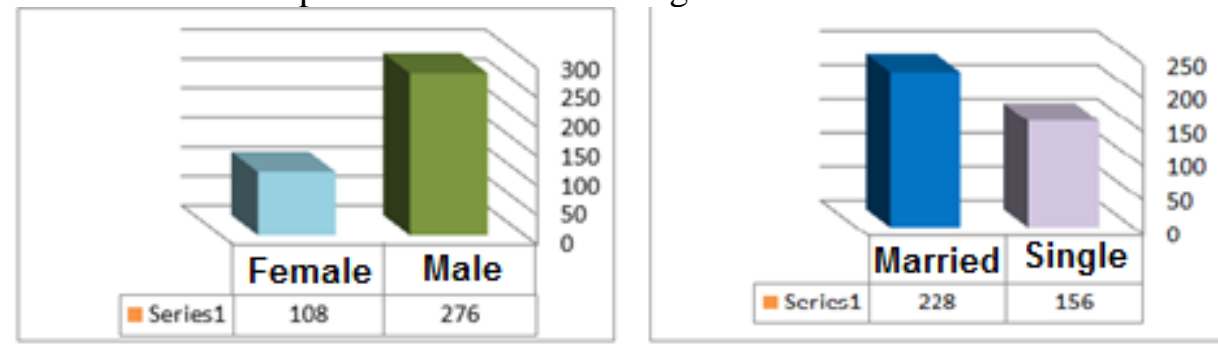

Statistics regarding age group of people show that most people are in the age group of 25 - 35 years and the lowest age group is related to people 55 years and older.

Chart 2. Descriptive information regarding age and education variables
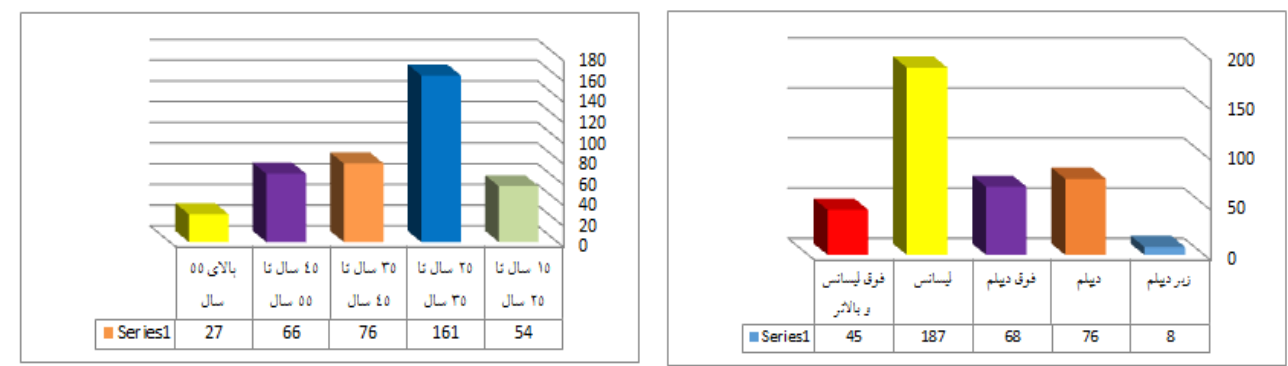

According to the statistics extracted regarding education, it is clear that the majority of the information collected belongs to people with a Bachelor's degree and the least to those below the diploma level.

\section{Inferential statistics}

Before determining the type of results, we need to make sure that the variables are normal. Therefore, we use the Kolomogorov-Smirnov test. In this test, if the probability level is larger than 0.05 (Sig> 0.05), its status is normal and parametric statistics should be used. If the 
probability level is smaller than 0.05 ( $\mathrm{Sig}<0.05$ ), its status is abnormal and non-parametric statistics should be used.

Table 5. Testing the variable normality hypothesis (Kolomogorov-Smirnov)

\begin{tabular}{|c|c|c|c|c|c|c|}
\hline No. & Questionnaire & Component & $\begin{array}{l}\text { Statistics Z } \\
\text { test K-S }\end{array}$ & $\begin{array}{l}\text { Probability } \\
\text { Level(Sig)) }\end{array}$ & Status & $\begin{array}{l}\text { Correlation } \\
\text { Test }\end{array}$ \\
\hline 1 & \multirow{5}{*}{$\begin{array}{l}\text { The investors' } \\
\text { personality }\end{array}$} & Extraversion & 2.901 & 0.179 & Normal & Pearson \\
\hline 2 & & Compatibility & 1.971 & 0.097 & Normal & Pearson \\
\hline 3 & & Conscientiousness & 1.425 & 0.144 & Normal & Pearson \\
\hline 4 & & Neuroticism & 2.151 & 0.219 & Normal & Pearson \\
\hline 5 & & Openness & 3.256 & 0.102 & Normal & Pearson \\
\hline \multicolumn{3}{|c|}{ Conservatism Questionnaire } & 2.144 & 0.065 & Normal & Pearson \\
\hline
\end{tabular}

In order to test the research hypotheses in terms of statistical significance, first the normality of distribution of scores was tested. The Table above summarizes the results of the SmirnovKolmogorov test. As seen, according to the relevant test, all nine components of the questionnaires are normal. Thus, Pearson correlation test should be used in significance calculations of hypotheses. Findings related to the main research hypothesis to test the hypothesis of the relationship between investors' personality and their conservatism in Tehran Stock Exchange using the results of Table 6 indicates that since the probability level value was less than 0.05 ( $\mathrm{Sig}<0.05$ ), therefore, the hypothesis of a relationship between the investors' personality and their conservatism is accepted in the Tehran Stock Exchange. Also, the value of Pearson correlation coefficient, which is equal to $0.662(\mathrm{R}=0.662)$ indicates that there is a moderate to high correlation between these two components. That is, enhancing investors' personalities increases their conservatism.

Table 6. Pearson correlation coefficient for two variables of personality and conservatism

\begin{tabular}{|l|l|l|l|l|}
\hline $\begin{array}{l}\text { Dependent variable } \\
\text { Independent } \\
\text { variable }\end{array}$ & \multicolumn{4}{|l|}{ Investors' Conservatism in Tehran Stock Exchange } \\
\cline { 2 - 5 } & $\begin{array}{l}\text { Pearson } \\
\text { coefficient }\end{array}$ & Sig & R Square & $\begin{array}{l}\text { std. Error of the } \\
\text { Estimate }\end{array}$ \\
\hline $\begin{array}{l}\text { The investors' } \\
\text { personality }\end{array}$ & 0.662 & 0.001 & 0.44 & 0.255 \\
\hline
\end{tabular}

Also, according to the test and based on regression and the results listed in Table 7, the accuracy of predicting the investors' personality is 0.44 . Thus, approximately $44 \%$ of investors' conservatism is calculated through a linear relationship with their personality (Beta $=0.622, \mathrm{R}$ Square $=0.44$ ).

Table 7. Linear regression analysis of two variables of personality and conservatism

\begin{tabular}{|l|l|l|l|l|l|}
\hline Sig & \multirow{2}{*}{ T } & $\begin{array}{l}\text { Standardized } \\
\text { Coefficients }\end{array}$ & \multicolumn{2}{|l|}{ Unstandardized Coefficients } & \\
\cline { 4 - 6 } & & Beta & Std. Error & B & \\
\hline 0.000 & 19.07 & 0.662 & 0.55 & 3.84 & (Constant) 1 investors' \\
\hline 0.001 & 7.05 & & 0.35 & 1.70 & $\begin{array}{l}\text { The } \\
\text { personality }\end{array}$ \\
\hline
\end{tabular}

In the following, in Table 8, the results of multivariate regression test for the variables of investors' personality and their conservatism in the stock exchange indicate that except for the independent variable of extraversion, other variables were recognized as significant. 
Table 8: Regression results to examine investors' conservatism in terms of personality

\begin{tabular}{|c|c|c|c|c|c|}
\hline $\begin{array}{l}\text { Second } \\
\text { question }\end{array}$ & Independent variables & $\begin{array}{l}\text { Dependent } \\
\text { variable }\end{array}$ & B & Sig & Test Result \\
\hline $\begin{array}{l}\text { Multivariate } \\
\text { Regression }\end{array}$ & $\begin{array}{l}\text { Extraversion } \\
\text { Compatibility } \\
\text { Conscientiousness } \\
\text { Neuroticism } \\
\text { Openness (flexibility) }\end{array}$ & $\begin{array}{l}\text { Investors' } \\
\text { conservatism }\end{array}$ & $\begin{array}{l}0.076 \\
0.173 \\
0.125 \\
0.093 \\
0.161\end{array}$ & $\begin{array}{l}0.102 \\
0.000 \\
0.007 \\
0.009 \\
0.001\end{array}$ & $\begin{array}{l}\text { Hypothesis } \\
\text { rejected } \\
\text { Hypothesis } \\
\text { accepted } \\
\text { Hypothesis } \\
\text { accepted } \\
\text { Hypothesis } \\
\text { accepted } \\
\text { Hypothesis } \\
\text { accepted }\end{array}$ \\
\hline & $2=0.448$ & \multicolumn{2}{|l|}{$\mathrm{F}=28.31$} & $\mathrm{~N}=384$ & $\mathrm{P}<05$ \\
\hline
\end{tabular}

According to Table 8 , the multivariate regression function of investors' conservatism based on their personality in Tehran Stock Exchange is as follows:

$$
\mathrm{Y}=0.173 \mathrm{X}_{2}+0.125 \mathrm{X}_{3}+0.093 \mathrm{X}_{4}+0.161 \mathrm{X}_{5}
$$

Where $Y$ represents investors' conservatism, $\mathrm{X}_{1}$ represents investors' extraversion, $\mathrm{X}_{2}$ represents investors' compatibility, $\mathrm{X}_{3}$ represents investors' conscientiousness, $\mathrm{X}_{4}$ represents investors' neuroticism, and $\mathrm{X}_{5}$ represents investors' openness (flexibility). The interpretation of the obtained regression function shows that the share of extroversion, compatibility, conscientiousness, neuroticism and openness (flexibility) of investors is equal to: $0.173,0.125,0.093$ and 0.161 , respectively. In general, the dimensions and variables of investors' personality predicted about $45 \%$ of the variance changes in their conservative variable.

In the following, a regression test was performed to investigate the hypothesis of a relationship between investors' extroversion and their conservatism in the Tehran Stock Exchange.

Table 9. Pearson correlation coefficient for extraversion and conservatism variables

\begin{tabular}{|c|c|c|c|c|}
\hline \multirow{2}{*}{$\begin{array}{c}\text { Dependent variable } \\
\text { Independent variable }\end{array}$} & \multicolumn{3}{|c|}{ Investors' Conservatism in Tehran Stock Exchange } \\
\cline { 2 - 5 } & $\begin{array}{c}\text { Pearson } \\
\text { coefficient }\end{array}$ & Sig & R Square & $\begin{array}{c}\text { Std. Error of the } \\
\text { Estimate }\end{array}$ \\
\hline $\begin{array}{c}\text { Investors' } \\
\text { extraversion }\end{array}$ & 0.192 & 0.103 & 0.036 & 0.251 \\
\hline
\end{tabular}

As Table 9 shows, there is no significant relationship between investors' extroversion and their conservatism with respect to $\mathrm{Sig}>0.05$. Therefore, extraversion has no effect on the conservatism of investors in the Tehran Stock Exchange.

Then, to examine the effect of investors' extroversion on the Tehran Stock Exchange and conservatism, as shown in Table 10, according to the regression table, the value was sig $>0.05$, therefore, the investors' extroversion on the Tehran Stock Exchange had no effect on their conservatism.

Table 10. Linear regression analysis of two variables of extraversion and conservatism

\begin{tabular}{|c|c|c|c|c|c|}
\hline \multirow{2}{*}{ Sig } & T & $\begin{array}{c}\text { Standardized } \\
\text { Coefficients }\end{array}$ & \multicolumn{2}{|c|}{ Unstandardized Coefficients } & Mode \\
\cline { 3 - 5 } & & Beta & Std. Error & B & \\
\hline 0.077 & 7.25 & 0.192 & 0.42 & 1.60 & (Constant) 1 \\
\hline 0.103 & 3.07 & & 0.28 & 1.19 & Investors' extraversion \\
\hline
\end{tabular}

In order to investigate the relationship between investors' compatibility and their conservatism in Tehran Stock Exchange, based on Table 11 and the value of sig $<0.05$, there is a significant relationship between investors' compatibility and their conservatism. The value of Pearson correlation coefficient $\mathrm{R}=0.816$ indicates that there is a high correlation between these two components, i.e. by improving investors' compatibility in Tehran Stock Exchange, their conservatism increases greatly. 
Table 11. Pearson correlation coefficient for compatibility and conservatism variables

\begin{tabular}{|c|c|c|c|c|}
\hline \multirow{2}{*}{ Dependent variable } & \multicolumn{3}{|c|}{ Investors' Conservatism in Tehran Stock Exchange } \\
\cline { 2 - 5 } Independent variable & $\begin{array}{c}\text { Pearson } \\
\text { coefficient }\end{array}$ & Sig & R Square & $\begin{array}{c}\text { Std. Error of the } \\
\text { Estimate }\end{array}$ \\
\hline $\begin{array}{c}\text { Investor's } \\
\text { Compatibility }\end{array}$ & 0.816 & 0.001 & 0.66 & 0.152 \\
\hline
\end{tabular}

In order to investigate the relationship between investors' compatibility and their conservatism in Tehran Stock Exchange, using the regression model, based on Table 12 and the value of sig < 0.05 , it is revealed that there is a significant relationship between investors' compatibility and their conservatism. The value of Pearson correlation coefficient $\mathrm{R}=0.816$ indicates that there is a high correlation between these two components, i.e. by improving investors' compatibility in Tehran Stock Exchange, their conservatism increases greatly.

Table 12. Linear regression analysis of two variables of compatibility and conservatism

\begin{tabular}{|c|c|c|c|c|c|}
\hline \multirow{2}{*}{ Sig } & $\mathrm{T}$ & $\begin{array}{c}\text { Standardized } \\
\text { Coefficients }\end{array}$ & \multicolumn{2}{|c|}{ Unstandardized Coefficients } & Mode \\
\cline { 3 - 5 } & & Beta & Std. Error & $\mathrm{B}$ & \\
\hline 0.000 & 28.72 & 0.816 & 0.21 & 4.98 & (Constant) 1 \\
\hline 0.001 & 19.04 & & 0.14 & 2.18 & Investors' Compatibility \\
\hline
\end{tabular}

According to regression test, the accuracy of predicting investors' compatibility is 0.66 ., therefore, almost $66 \%$ of investors' conservatism is calculated through a linear relationship with their compatibility (Beta $=\mathbf{0 . 8 1 6}$, $\mathrm{R}$ Square $=\mathbf{0 . 6 6}$ also to investigate the relationship between investors' conscientiousness and their conservatism in Tehran Stock Exchange, as Table 13 and the value Sig $<0.05$ indicate, investors' conscientiousness has a significant relationship with their conservatism. Considering the value of Pearson correlation coefficient $\mathrm{R}=0.494$, it is indicated that there is a relative relationship between these two components. That is, by improving the investors' neuroticism in Tehran Stock Exchange, their conservatism increases relatively.

Table 13. Pearson correlation coefficient for conscientiousness and conservatism variables

\begin{tabular}{|c|c|c|c|c|}
\hline \multirow{2}{*}{$\begin{array}{c}\text { Dependent variable } \\
\text { Independent variable }\end{array}$} & \multicolumn{3}{|c|}{ Investors' Conservatism in Tehran Stock Exchange } \\
\cline { 2 - 5 } & $\begin{array}{c}\text { Pearson } \\
\text { coefficient }\end{array}$ & Sig & R Square & $\begin{array}{c}\text { std. Error of } \\
\text { the Estimate }\end{array}$ \\
\hline $\begin{array}{c}\text { Investors' } \\
\text { Conscientiousness }\end{array}$ & 0.494 & 0.009 & 0.24 & 0.190 \\
\hline
\end{tabular}

According to the regression test contained in Table 14, the accuracy of predicting the investors' neuroticism is 0.24 . Therefore, approximately $24 \%$ of investors' conservatism was calculated through a linear relationship with their conscientiousness $($ Beta $=\mathbf{0 . 4 9 4}$, R Square $=0.24)$.

Table 14. Linear regression analysis of two variables of conscientiousness and conservatism

\begin{tabular}{|c|c|c|c|c|c|}
\hline \multirow{2}{*}{ Sig } & \multirow{2}{*}{\begin{tabular}{c} 
S \\
\cline { 4 - 5 }
\end{tabular}} & $\begin{array}{c}\text { Standardized } \\
\text { Coefficients }\end{array}$ & \multicolumn{2}{|c|}{ Unstandardized Coefficients } & Mode \\
\cline { 4 - 6 } & Beta & Std. Error & $\mathrm{B}$ & \\
\hline 0.003 & 19.12 & 0.494 & 0.36 & 3.22 & (Constant) 1 \\
\hline 0.009 & 10.62 & & 0.18 & 1.65 & $\begin{array}{c}\text { Investors' } \\
\text { Conscientiousness }\end{array}$ \\
\hline
\end{tabular}

To investigate the investors' neuroticism with their conservatism in Tehran stock exchange, the regression test to investigate this hypothesis is as follows: 
Table 15. Pearson correlation coefficient for neuroticism and conservatism

\begin{tabular}{|c|c|c|c|c|}
\hline Dependent variable & \multicolumn{3}{|c|}{ Investors' Conservatism in Tehran Stock Exchange } \\
\cline { 2 - 5 } Independent variable & $\begin{array}{c}\text { Pearson } \\
\text { coefficient }\end{array}$ & Sig & R Square & $\begin{array}{c}\text { std. Error of the } \\
\text { Estimate }\end{array}$ \\
\hline $\begin{array}{c}\text { Investors' } \\
\text { Neuroticisms }\end{array}$ & -0.322 & 0.011 & 0.10 & 0.237 \\
\hline
\end{tabular}

Based on the Table 15 and the value Sig $<0.05$, there is a significant relationship between investors' neuroticism and their conservatism. Considering the value of Pearson correlation coefficient $R=$ -0.322 , this value indicates that there is a weak relationship between these two components which is inverse. That is, with the increase in the investors' neuroticism in the Tehran Stock Exchange, their conservatism decreases slightly.

Table 16. Linear Regression Analysis of Neuroticism and Conservatism

\begin{tabular}{|c|c|c|c|c|c|}
\hline Sig & \multirow{2}{*}{} & $\begin{array}{c}\text { Standardized } \\
\text { Coefficients }\end{array}$ & \multicolumn{2}{|c|}{ Unstandardized Coefficients } & \multirow{2}{*}{ Mode } \\
\cline { 3 - 5 } & & Beta & Std. Error & $\mathrm{B}$ & \\
\hline 0.004 & 9.62 & -0.322 & 0.35 & 3.09 & (Constant) 1 \\
\hline 0.011 & 6.12 & & 0.21 & 1.29 & Investors' Neuroticisms \\
\hline
\end{tabular}

According to the regression test, the predicted accuracy of investors' neuroticism is 0.10 . Therefore, approximately $10 \%$ of investors' conservatism has been calculated through a linear relationship with their neuroticism. (Beta $=\mathbf{- 0 . 3 2 2}, \mathrm{R}$ Square $=\mathbf{0 . 1 0})$

To investigate the openness (flexibility) of investors with their conservatism in Tehran Stock Exchange, the regression test to investigate this hypothesis is as follows:

Table 17. Pearson correlation coefficient for openness and conservatism variables

\begin{tabular}{|c|c|c|c|c|}
\hline $\begin{array}{c}\text { Dependent variable } \\
\text { Independent } \\
\text { variable }\end{array}$ & \multicolumn{3}{|c|}{ Investors' Conservatism in Tehran Stock Exchange } \\
\cline { 2 - 5 } & $\begin{array}{c}\text { Pearson } \\
\text { coefficient }\end{array}$ & Sig & R Square & $\begin{array}{c}\text { std. Error of the } \\
\text { Estimate }\end{array}$ \\
\hline $\begin{array}{c}\text { Investors' Openness } \\
\text { (flexibility) }\end{array}$ & 0.762 & 0.004 & 0.58 & 0.188 \\
\hline
\end{tabular}

Based on the Table 17 and the value Sig $<0.05$, there is a significant relationship between investors' openness (flexibility) and their conservatism. Considering the value of Pearson correlation coefficient $\mathrm{R}=0.762$, this value indicates that there is a strong relationship between these two components. That is, with the increase in the investors' openness (flexibility) in the Tehran Stock Exchange, their conservatism increases greatly.

Table 18. linear regression analysis of openness and conservatism

\begin{tabular}{|c|c|c|c|c|c|}
\hline \multirow{2}{*}{ Sig } & \multirow{2}{*}{$\mathrm{T}$} & $\begin{array}{c}\text { Standardized } \\
\text { Coefficients }\end{array}$ & \multicolumn{2}{|c|}{ Unstandardized Coefficients } & \multirow{2}{*}{ Mode } \\
\cline { 4 - 5 } & & Beta & Std. Error & $\mathrm{B}$ & \\
\hline 0.001 & 26.11 & 0.762 & 0.24 & 4.68 & (Constant) 1 \\
\hline 0.004 & 16.82 & & 0.16 & 2.05 & $\begin{array}{c}\text { Investors' Openness } \\
\text { (flexibility) }\end{array}$ \\
\hline
\end{tabular}

Based on the regression test, the accuracy of predicting investors' openness (flexibility) is 0.58 . Thus, approximately $58 \%$ of investors' conservatism is calculated through a linear relationship with their openness (flexibility). 


\section{Discussion and conclusion}

In the present study, an attempt was made to investigate the relationship between investors' personalities and their conservative behavior in Tehran Stock Exchange. Finally, descriptive and inferential statistics showed that there is a moderate to high relationship between the investors' personality and their conservatism. The results of this study showed that there is a significant relationship between the investors' personality and their conservatism in Tehran Stock Exchange. Since the probability level was $\mathrm{p}<0.05$, therefore, the main hypothesis of a relationship between investors' personality and their conservatism is accepted in Tehran Stock Exchange. Also according to the value of Pearson correlation coefficient which was 0.662 , it was shown that there is a medium to high relationship between these two components. Then, based on the regression test, the accuracy of predicting the investors' personality is 0.44 . That is, approximately $44 \%$ of investors' conservatism is calculated through a linear relationship with their personality. Also multivariate regression equation

$$
\mathrm{Y}=0.173 \mathrm{X}_{2}+0.125 \mathrm{X}_{3}+0.093 \mathrm{X}_{4}+0.161 \mathrm{X}_{5}
$$

shows that the share of compatibility, conscientiousness, neuroticism and openness (flexibility) of investors is equal to: $0.173,0.125,0.093$ and 0.161 , respectively. It was also shown that extroversion has no effect on individuals' conservatism. Standard financial science is basically based on rules about how investors should behave, rather than on principles that describe how they actually behave. Behavioral finance seeks to identify active human psychological phenomena in financial markets. However, standard financial science has based its assumptions on ideal financial behavior while behavioral financial assumptions are based on observed financial behavior. In addition, personality is one way to portray human characteristics, usually referred to as a number of relatively fixed behavioral features or characteristics. Kaplan and Sadock (1982) have also defined personality as a general diagnostic label for a person's observable behavior and his expressible inner (mental) experiences (Mollayi, 2010).

Based on the findings of this study, we can make the following suggestions in order to make the right decisions and away from the influence of investors' behavioral biases:

1- Dealing with investors' mistakes by equipping investors with sufficient knowledge about behavioral financial sciences though holding courses and providing useful information about the internal factors affecting investors' decisions.

2- It is better for people to control their emotions and feelings in buying and selling stocks and to trade based on facts and documents.

3- Establishing companies providing consulting services in order to update people's information.

4- Those who have studied in financial fields should try to buy and sell shares.

Finally, it is suggested to conduct further research in the areas of behavioral finance to test the various cognitive deviations that may exist in the market. Research that can be recommended in future work can include examining the relationship between investors 'values and attitudes with perceptual errors and examining the relationship between investors' feelings and perceptual errors. Other errors such as stereotypes, halo effects (generalization of a company's positive character to all factors) that can affect the behavior of investors can also be considered in the future. The relationship between culture, personality and perceptual errors of investment is also one of the cases that need further research.

\section{References}

Abdolrahimian, Mohammad Hossein, Torabi, Taghi, Sadeghi Sharif, Seyed Jalal, Darabi, Roya (2018). Presenting the behavioral pattern of real investors' decision-making in Tehran Stock Exchange. Journal of Investment Knowledge, Vol. 7, issue 26, pp. 129-113

Adetiloye, K. A. (2012). Investors' Behavioral Biases And The Security Market: An Empirical Study Of The Nigerian Security Market" . Accounting and Finance Research, Vol. 1,No. 1.

Ahmadi, Ali Akbar and Salehi, Ali (2012), Research Methodology in Management, Tehran: Payame Noor Publications 
Azar, Adel and Momeni, Mansour (2006). Statistics and its application in management, Tehran: Samt Publications.

Bazargan, Abbas; Sarmad, Zohreh, Hejazi, Elahe (2006). Research Method in Behavioral Sciences, Tehran: Agah Publishing.

Bikhchandalli,Sushil and Sharma slunil.(2001),"Herd behavior in financial markets" International Monetary Fund,47(3),pp.279-31

Ebrahimi, Khadijeh, Dastgir, Mohsen, Latifi, Zohreh (2017). Assessing the importance of personality traits of capital market analysts as a third dimension of their success. Scientific Research Quarterly of Investment Knowledge, Vol. 6, issue 22, pp. 87-100

Eslami Bidgoli Gholamreza (2008). Topics in Financial Theory and Management, Tehran: Termeh Publications

Farhang, Qaraguzlu, (2008). Investigating the over-confidence of investors and the volume of transactions on the Tehran Stock Exchange. Master's Thesis in Financial Management, Faculty of Management and Accounting, Shahid Beheshti University

Farzaneh Pi, Alireza (2006). Investigating the relationship between needs and the five major personality factors. Master's Thesis in Clinical Psychology, Islamic Azad University, Research Sciences Branch.

Jafari Kang, M., Khodadadifard, M., Afandizadeh, S. (2017). Providing a Decision-Making Method for Evaluation of Exclusive BRT lanes Implementation Using Benefit-Cost Analysis - Case Study: Tehran BRT line 4. Journal of civil Engineering and Materials Application, 1(1), 8-15.

Jahankhani, Ali, Noferesti, Mohammad, Qaraguzlu, Farhang (2009). Investigating the overconfidence of investors and the volume of transactions on the Tehran Stock Exchange. Business Management Perspectives, Spring 2009, p.105

Kahneman, D., \& Tversky, A. (1979). "Prospect theory: An analysis of decision under risk". Econometrica, 47(6), 263- 291

Khoshnood, Mehdi (2004). Identifying and ranking of groups influencing the decision making of individual and institutional investors in Tehran Stock Exchange. Master Thesis in Financial Management, University of Tehran.

Knoll, M. A. (2010). "Role Of Behavioral Economics And Behavioral Decision Making In Americans' Retirement Savings Decisions" . social security bulletin, vol. 70, No .4.

Kothari, S., P., Lewellen, ., Warner, J., B., (2006), "stock returns, aggregate earnings surprises and behavioral finance Journal of Financial Economics" 79 537-568.

Koubrich et all (1998), Volume, "Volatility, Price and Profit When All Traders are Above Average", Journal of Finance, Vol. 53, No. 5, pp 1775-1798

Man dler, M. (1999). "Dilemmas in economic theory: Persisting foundational problems of microeconomics". New York:Oxford University Press

Moghimi, Sayed Mohammad (1998). Organization and management of research approach. Tehran: Termeh Publications.

Naseri, F., Bagherzadeh Khalkhali, A. (2018). Evaluation of Seismic Performance of Concrete Gravity Dams Under Soil-structure-reservoir Interaction Exposed to Vertical Component of Near-field Earthquakes During Impounding Case study: Pine Flat Dam. Journal of civil Engineering and Materials Application, 2(4), 181-191.

Paluch, D. (2011). "Overconfidence Bias In Decision Making At Different Levels Of Management" . Gorden Institute of Business Science..

Peterson, R. L., (2007), "Affect and Financial Decision Making: How Neuroscience Can Inform Market Participants".The Journal of Behavioral Finance, Vol. 8, No. 2, pp. 70-78.

Pompian, Michael M. (2009). Behavioral financial knowledge and asset management, trans. Dr. Ahmad Badri, Tehran: Kayhan Publications.

Raei, Reza and Fallahpour, Saeed (2004). Behavioral tax, a different approach to the field of finance. Financial Research, Issue 85, pp. 77-106

Ritter,R.y.(2003), "Behavioral Finance" , Pasific- Busin Finance Journal - 429-437.

Saadi, Rasoul, Gholipour, Arian, Gholipour, Fataneh, (2010). Investigating the effects of investors' personality and perceptual errors in their investment in Tehran Stock Exchange. Financial Research, Vol. 12, issue 29 
Sedghi Khorasgani, Hossein (2007). Dominant behavioral styles of investors in Tehran stock market. Capital newspaper, Issue. 542, p.18.

Shahriari, Sara (2006). Investigating and testing the mass behavior of investors using deviations of stock returns from total market returns in the Tehran Stock Exchange during the years 2001 to 2005. Master's Thesis, University of Tehran.

Shaker, H., Bigdeli Rad, H. (2018). Evaluation and Simulation of New Roundabouts Traffic Parameters by Aimsun Software. Journal of civil Engineering and Materials Application, 2(3), 146-158.

Shefrin H. (2005). "Do Investors Expect Higher Return From Safer Than Riskier Stock", Journal of Psychology \& Financial Market.

Sing\& Kansal. (2013). "Investment behaviour of Indian Investors: Gender Biasness, Proceedings of Seventh National Conference on Indian Capital Market": Emerging Issues, IBS Gurgaon, India, February 11-12, 2013.

Sternberg, Robert (2008). Psychology of Cognition, trans. Dr. Kamal Kharazi and Dr. Elahe Hejazi. Tehran: Tehran Cognitive Sciences Research Institute.

Taqqadus Bashir, Scholar et al (2013). "Impact of Behavioral Biases on Investors Decision Making: Male Vs Female", IOSR Journal of Business and Management (IOSR-JBM) eISSN: 2278-487X, p-ISSN: 2319-7668. Volume 10, Issue 3 (May. - Jun. 2013), PP 6068

Telangi, Ahmad (2004). Confrontation of New Theory of Finance and Behavioral Finance. Journal of Financial Research, Faculty of Management, University of Tehran, Issue 17.

Thaller, R. (1992). "The winner's curse: Paradoxes and anomalies of economic life". New York: Free Press 148- 173. 